\title{
The Effects of Technological Innovation, Organizational Innovation and Absorptive Capacity on Product Innovation: A Structural Equation Modeling Approach
}

\author{
Wang Z. Min ${ }^{1}$, Kwek C. Ling ${ }^{2} \&$ Tan, H. Piew ${ }^{3}$ \\ ${ }^{1}$ Faculty of Business and Information Science, UCSI University, Kuala Lumpur, Malaysia \\ ${ }^{2}$ Faculty of Accountancy, Business and Finance, TARUC, Kuala Lumpur, Malaysia \\ ${ }^{3}$ Faculty of Accountancy and Management, UTAR, Selangor, Malaysia \\ Correspondence: Kwek Choon Ling, Faculty of Accountancy, Business and Finance, TARUC, Kuala Lumpur \\ Campus, Jalan Genting Kelang, Setapak, 53300 Kuala Lumpur, Malaysia. E-mail: kwekcl@acd.tarc.edu.my
}

Received: September 28, 2015 Accepted: November 11, 2015 Online Published: December 21, 2015

doi:10.5539/ass.v12n1p199 URL: http://dx.doi.org/10.5539/ass.v12n1p199

\begin{abstract}
This study investigates the impacts of organizational innovation, technological innovation and absorptive capacity on product innovation as well as examines the antecedents of technological innovation and organizational innovation in one of the Tertiary Education Institutions in Malaysia. A total of 600 samples were distributed to the tertiary students. A questionnaire survey was adopted as the main method of data collection and structural equation modeling was applied as a data analysis tool. The findings indicate that: (1) Organizational innovation, technological innovation and absorptive capacity are positively related to product innovation respectively; (2) Technological innovation positively mediates the relationship between organizational innovation and product innovation; (3) Technological innovation positively mediates the relationship between absorptive capacity and product innovation; (4) Organizational innovation positively mediates the relationship between absorptive capacity and technological innovation; (5) Organizational innovation positively mediates the relationship between absorptive capacity and product innovation. The findings of this study do provide relevant theoretical, managerial and policy contributions in the literature.
\end{abstract}

Keywords: absorptive capacity, technological innovation, organizational innovation, product innovation

\section{Introduction}

The evolution of innovation concepts and models had been presented in the literature since 1890s. Innovation is a multiple discipline area in which it encompasses economics, politics, law, science, education, sociology, anthropology and religion (Redfield et al., 1936; Barnett, 1953). Schumpeter was one of the pioneer economists that creating the classification of technical change types in year 1912 and the destruction concept of innovation in year 1932 and 1934 (Schumpeter, 1942). After the Second World War, the works on innovation were initiated by a few scholars, such as economics of technological change proposed by Maclaurin (1947, 1949, 1953); conceptualization of technological innovation as new combination of means of production (Lange, 1943); innovation as commercialized invention in new product concept (Jewkes, 1958) and the emergence of organizational innovation concept (Cole, 1959). Innovation has been identified as the main factor for strengthening the competitiveness of the organizations (OECD, 1991) and innovation also changes the organization's product market domain (Floyd \& Lane, 2000). From the perspective of "change of technological paradigm", a few key innovation models were presented, including the innovation process (Utterback, 1975; Cooper, 1980), technological innovation (Damanpour \& Aravind, 2011), management innovation (Vacaro, 2010), organizational innovation (OECD, 2005) and product innovation (Pine e Cunha et al, 2014). However, these researchers fail to make a distinction between these types of innovation and how these innovations interact with each other in the innovation study. Therefore, this research will primarily focus on studying the interaction effects among the product innovation, organizational innovation and technological innovation. According to Chesbrough (2003), some firms in the high-technology industries have shifted their innovation efforts from a "Closed Innovation Model" to an "Open Innovation Model". Open Innovation can be defined as "the use of purposive inflows and outflows of knowledge to accelerate internal innovation, and expand the markets for 
external use of innovation, respectively" (Chesbrough, 2003, p. 1). In order to gain inflows and outflows of knowledge, firms should have to get "absorptive capacity" to obtain knowledge. However, there is a lacking of study in evaluating the role of absorptive capacity in mediating the relationships among the product innovation, organizational innovation, technological innovation.

The main objective of this research is to evaluate the interactive effects among absorptive capacity, organizational innovation, technological innovation and product innovation. The second objective of this study is to evaluate the determinants of product innovation in the tertiary education sector in Malaysia. Nowadays, the tertiary education institutions are highly competitive because of the rapid changes and the stringent policies required in the educational environment, new technology, variety of the academic programs, and the requirement of having higher knowledge management capacity in implementing the transformation process in the tertiary education sector (Herbst \& Conradie, 2011).

\section{Literature Review}

\subsection{Theoretical Background}

A firm's absorptive capacity is closely related to its innovation. According to Cohen and Levinthal (1990), absorptive capacity theory elaborated that the ability of a firm to learn from others may enable the firm to improve its own R\&D. Therefore, absorptive capacity theory is an important argument in which the firm internal R\&D need to be integrated with the external knowledge (Cohen \& Levinthal, 1990). Theoretically, the absorptive capacity concept can be identified in the field of organizational learning (Huber, 1991); dynamic capabilities (Monwery, Oxley \& Silverman, 1996) and knowledge management (Chiva \& Alerge, 2005). Learning theories can be considered as the creation and application of knowledge at various levels; the centrality of learning is related to the organizational performance; the construction of learning can be at the individual and group levels; and the ways in which individual learning can become an organizational property (Argyris \& Schon, 1978; Senge, 1990; Nonaka \& Takeuchi, 1995; Cook \& Brown, 1999). According to Teece, et al. (1997), "dynamic capabilities theory" encompasses the ability of firms to learn and to sense the need for changes and then reconfigure internal and external competences to seize opportunities in the rapidly changing environments. "Dynamic capabilities theory" asserted that the firm will be able to create, transfer, assemble, integrate and exploit its dynamic knowledge assets and capabilities that hardly to be imitated by the competitors (Teece, et al., 1997).

\subsection{Product Innovation}

Organizational renewal involves the building and expansion of organizational competences over time, often involving a change in the organization's product market domain (Floyd \& Lane, 2000). According to Floyd and Lane (2000, p. 155), 'a theory of strategic renewal must recognize that maintaining adoptiveness requires both exploiting existing competencies and exploring new ones.' Eisenhardt and Martin (2000) argued that acquisitions, alliance formation and product innovation are some of the organizational activities that serve to renew and reconfigure organizational resources. Eisenhardt and Martin (2000) also asserted that product development is a dynamic capability of the firm because of its ability to alter the resource configuration of the firm. Helfat and Raubitschek (2000) argued that organizational capabilities and products co-evolve over time. Therefore, this research would like to assess the impacts of the organizational capabilities (such as absorptive capacity, technological innovation and organizational innovation) on product innovation.

Product innovation can be defined as the development or creation driven by a desire to improve the properties and performance of completed products (Lager, 2002). Product innovation is traditionally at the core of the innovation strategy. It encompasses the creation of radically new products (characterized by new functions, new functional principles, less functions, and additional functions) as well as the incremental change and / or improvement of existing products (Ettlie, Bridges, \& O'Keefe, 1984; Pleschak \& Sabisch, 1996; Tidd, Bessant \& Pavitt, 2005; Disselkamp, 2005; Reichwald \& Piller, 2006; Krubasik \& Pale, 1988). Therefore, product innovation includes "new products or services introduced to meet an external user or market need" (Damanpour \& Gopalakrishnan, 2001, pp. 47-48). However, research also shows that product innovation could be risky for the organization. According to Gupta and Wilemon (1990), the risks may involve the poor definition of product requirements; poor project management; lack of senior management support; lack of resources; and technological uncertainty can impede product development efforts.

\subsection{Technological Innovation}

Technological innovation can be the source of competitive advantage and value creation for organization operation (Spende, 1996). Technological innovation is defined as a technology new to the firm in which the 
innovation can be in the form of incremental, radical, ultimate, modest, pioneering, modified, and discontinuous (Grulke \& Sibler, 2003; Christense \& Raynor, 2003). Drawing on the definition offered by Tushman and Anderson $(1986,1990)$, these types of innovations are characterized by a technical advance so significant that no increase in scale, efficiency, or design can make older technologies competitive. Murat and Baki (2011) as well as Guan and Liu (2007) operationalise the concept of technological innovation that encompasses the rate of process innovation into the firm; firm focuses on process innovation; perception of novelty of new processes offered; and make full use of external technology to spearhead the process innovation. There are two yardsticks to measure the technology innovation, including (1) Perception of the market: market novelty, new functions proposed to customers; and (2) Strategic output: impact on the competitive position of the firms (Cooper, 1979; Cooper \& de Brentani, 1991; Ali et al., 1995). According to Durand (1992), there are three different perspectives can be adopted to analyze the intensity and the significance of technical change, including: 1) Technological input: technical novelty or scientific merit; 2) Competence throughput: new requirements on the competencies (resources, skills and knowledge); and 3) transilience.

Technological innovation is closely related to the techno-economic paradigm. According to Coccia (2005), the techno-economic paradigm encompasses clusters of radical and incremental innovations and it embraces several 'new technology systems'. As the result of emerging techno-economic paradigm, the concept 'technological regime' was created in studying the research in related to the technology innovation. In addition, the shifting of Techno-economic paradigm is relied on the combinations of radical product, process and organizational innovations. Moreover, the market pull and technology push will be generated from technological innovation (Darroch \& Jardine, 2002) and for this reason innovations are often characterized as incremental versus radical. Dosi (1988) stated that an incremental innovation is more likely to be a market pull innovation; while Van de Ven and Garud (1993) asserted that the radical innovation is normally generated by scientists and often incorporates new technologies or new combinations of existing technologies. Therefore, radical innovation is often a technology push innovation (Cooper, 1979; Green et al., 1995; O’Connor, 1998). However, the firms has been facing the increased competition and an accelerating pace of technological change, the non-technological innovation has been identified but which is more challenge and difficult to replicate (Teece, 1986). The non-technological innovation has been recognized as administrative innovation, organization innovation and management innovation (Damanpour \& Aravind, 2011).

\subsection{Organizational Innovation}

The first scientific studies on innovation in firms were on administrative innovation in which administrative innovation was defined as concerning changes in organizational structure and human resource practices (Daft, 1978; Damanpour \& Evan, 1984; Damanpour, Szabat, \& Evan, 1989; Damanpour, 1991; Ettlie \& Reza, 1992). Currently, more research papers refer innovation in firms as the management innovation (Hamel, 2006, 2007, 2009; Mol \& Birkinshaw, 2009); organizational innovation (OECD, 2005; Armbruster et al., 2006; Battisti \& Stoneman, 2010); or managerial innovation (Damanpour \& Aravind, 2011). Damanpour and Aravind (2011, p. 35 ) argued that the definitions of administrative, organizational and management innovations overlap remarkably. Particularly, organizational innovation can be viewed as the implementation of a new organizational method in a firm's business practices, workplace organization, or external relationships (OECD, 2005). The character that differentiates the organizational innovation from other organizational changes is the implementation of an organizational method that has not been applied before in the firm and that is the result of strategic management decisions (OECD, 2005). According to the OECD (2005), organizational innovation in business practices comprised the implementation of new methods for organizing routines and procedures, such as establishing databases for best practice, improving worker retention, or introducing management systems. However, most of the definitions created for organizational innovation or management innovation include the use of new managerial concepts and practices (Armbruster et al., 2006, 2008; Birkinshaw et al., 2008). As the definitions of organizational innovation differ in the literature, it is suggested that a further twist to the definition of organizational innovation (OECD, 2005; Armbruster et al., 2006, 2008; Battisti \& Stoneman, 2010) is required. Organizational innovation is defined as the foundation for the firm's sustainable performance as well as the growth engine of the firm (Santos, Doz, \& Williamson, 2006). Santos et al. (2006) asserted that the components of information technology that are adopted in the organizational innovation may enable the firm to force its competitors to create new specialized knowledge that focusing on the firm survival and growth cycle. Thus, Lloyd and William (2014) proposed a simple yet comprehensive conceptualization of the organizational innovative process that comprising broad stages: 1) knowledge accumulation; (2) formulation of an innovation; (3) decision; (4) implementation; and (5) diffusion. 


\subsection{Absorptive Capacity}

The concept of "absorptive capacity" (Flatten et al., 2011) has been used in investigating knowledge transfer between organizations (Andersén \& Kask, 2012). Theoretically, the absorptive capacity concept can be identified in the field of organizational learning (Huber, 1991), dynamic capabilities (Mowery, Oxley, \& Silverman, 1996), and knowledge management (Chiva \& Alegre, 2005). Cohen and Levinthal (1990) stated that most of the authors only slightly modify the definition of absorptive capacity. According to Kim (1997, 1998), the absorptive capacity can be defined as the capacity to learn and solve problems. Cohen and Levinthal (1990) defined absorptive capacity as the "ability of the firm to recognize the value of new, external information, assimilate it and apply it to commercial ends". Andersén (2012), Martinkenaite (2012) and Tseng et al. (2011) defined absorptive capacity as "the capability of recognizing, assimilating, and applying external knowledge". Zahra and George (2002, p. 186) further defined the absorptive capacity as "a set of organizational routines and processes by which firms acquire, assimilate, transform and exploit knowledge to produce a dynamic organizational capability that "pertaining to knowledge creation and utilization, which enhances a firm's ability to gain and sustain a competitive advantage". Zahra and George (2002) separate the absorptive capacity structure into two main dimensions: potential absorptive capacity (the capability to acquire and assimilate knowledge) and realized absorptive capacity (the transformation and exploitation of knowledge). In addition, absorptive capacity also consists of three dimensions: "i) the firm's relationship to its external environment; ii) the structure, routines, and knowledge base of the main value creation group(s); and iii) individuals' absorptive abilities" (Matusik \& Heeley, 2005 , p. 550). Several researchers have found that absorptive capacity could be exploited to measure the ability or power of an organization to apply outside knowledge (Koza \& Lewin, 1998). Kedia and Bhagat (1988) stated that there are few scholars used absorptive capacity to describe an organization's receptivity to technological, organizational and product innovations.

\subsection{The Relationships among Product Innovation, Organizational Innovation, Technological Innovation and Absorptive Capacity}

The relationships among product innovation, organizational innovation, technological innovation and absorptive capacity are illustrated in the extant literature. Guan and Liu (2007) asserted that the technological innovation and organizational innovation have the integrated and interactive relationship. While Jose Garrido and Camarero (2009) stated that "technological innovation can be effectively practiced with the aid of organizational innovation". The study from Garrido and Camarero (2009) also proved that there is a relationship between technological innovation and product innovation as well as the "product innovation can be effectively practiced with the aid of organizational innovation".

In related to the concept of absorptive capacity, Rahomee Ahmed Aljanabi et al. (2014) confirmed that the absorptive capacity is working well in corresponding with technological innovation because their study revealed that "technological innovation can be effectively practiced with the aid of absorptive capacity" in which the absorption of external knowledge can be pushed for technology improvement and changing. Besides, Chen and Chang (2012) confirmed that "absorptive innovation can be effectively practiced with the aid of organizational innovation." Cantner and Pyka (1998) argued that building up "the absorptive capacity is a superior strategy for acquiring external knowledge for product innovation." Therefore, Murovec and Prodan (2008) concluded their research finding by asserting that there is a "strong positive and statistically significant relationship between the extent of the absorptive capacity and the extent of product innovation."

However, there is a lacking of study in evaluating the role of absorptive capacity in mediating the relationships among the product innovation, organizational innovation, and technological innovation. The extant literature only concludes the antecedent relationships between absorptive capacity and technological innovation (Aljanabi et al., 2014); absorptive capacity and product innovation (Murovec \& Prodan, 2008); technological innovation and product innovation (Garrido \& Camarero, 2009); organizational innovation and product innovation (Garrido \& Camarero, 2009); organizational innovation and technological innovation (Guan \& Liu, 2007; Garrido \& Camarero, 2009); technological innovation and product innovation (Garrido \& Camarero, 2009). Based on the above findings, it is clearly a lacking of evaluating the mediating relationships for the following: (1) organizational innovation mediated the relationship between absorptive innovation and technological innovation; (2) organizational innovation mediated the relationship between absorptive capacity and product innovation; and (3) technological innovation mediated the relationship between absorptive capacity and product innovation. Thus, these findings from the extant literature create research gaps for this research and conceptual framework has been proposed in Figure 1. From the conceptual framework, ten hypotheses were established for further verification (as highlighted in Table 2). 


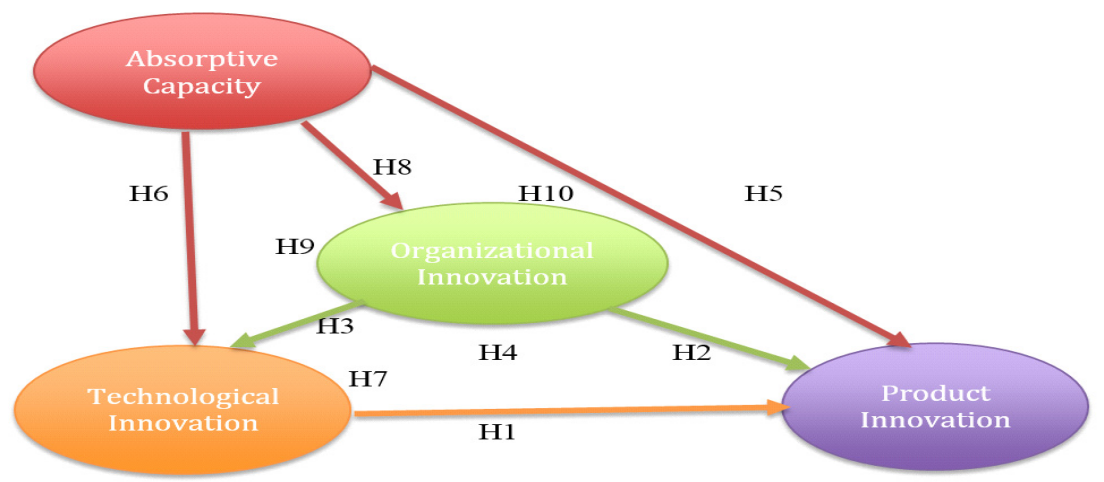

Figure 1. Proposed conceptual framework

Table 1. Hypotheses for this research

H1: Technological innovation is positively related to product innovation.

$\mathrm{H} 2$ : Organizational innovation is positively related to product innovation.

H3: Organizational innovation is positively related to technological innovation.

H4: Technological innovation mediates the relationship between organizational innovation and product innovation.

H5: Absorptive capacity is positively related to product innovation.

H6: Absorptive capacity is positively related to technological innovation.

H7: Technological innovation mediates the relationship between absorptive capacity and product innovation.

H8: Absorptive capacity is positively related to organizational innovation.

H9: Organizational innovation mediates the relationship between absorptive capacity and technological innovation.

H10: Organizational innovation mediates the relationship between absorptive capacity and product innovation.

\section{Methodology}

From the research methodology perspective, quantitative research was adopted in this study because a large scale of survey research study would be carried out with the intention to examine the theoretical relationships between variables that are measured numerically and analysed by using a range of statistical techniques to ensure data validity (Saunders et al., 2012; Kumar, Talib, \& Ramaysh, 2013). Primary data would be collected via cross-sectional study. A total of 600 tertiary students participated in this study via self-administrated questionnaire survey by rating the items in related to the innovations and absorptive capacity. A systematic sampling technique was applied in this research to identify the relevant samples.

All the scale measurements for the tested constructs in this research were sourced by the relevant literature, including the absorptive capacity was measured by five items that sourcing from Chen (2012); technological innovation was measured by four items that sourcing from Garrido and Camarero (2009); organizational innovation was measured by three items that sourcing from Garrido and Camarero (2009); product innovation was measured by three items that sourcing from Murovec and Prodan (2008). All the tested items would be evaluated by five point Likert scale, ranging from 1 (strongly disagree) to 5 (strongly agree).

A pilot test was carried out to ensure all items in the questionnaire were understandable, clear and readable and gave researchers the opportunity to make important amendments (Zikmund et al., 2010). Upon receiving 543 valid questionnaires from the actual survey, a series of statistical analysis were performed, including preliminary analysis, descriptive analysis, scale measurement and inferential analysis. 


\section{Data Analysis}

\subsection{Preliminary Analysis}

For the purpose of ensuring the quality of the research findings, different preliminary analyses were evaluated in this research, including non-response bias analysis, common method variance analysis and the test of normality assumption.

According to Armstron and Overton (1977), there are many approaches to deal with non-response bias. Armstron and Overton (1977) advocated that a more rigorous process of applying the extrapolation method, for instance the adoption of a two tail $\mathrm{T}$ test to ensure that the target sample set was similar with respect to those respondents who had submitted early and those who had submitted late with prompting. Baxter et al. (2012) proposed that independent sample T-test will be used to evaluate non-response bias analysis if there is a difference between their responses. Armstron and Overton (1977) and Baxter et al. (2012) suggested a rule of thumb for identifying non-response bias at the $\mathrm{p}>0.05$ level, which can be concluded as a significant difference and implied the existence of non-response bias. Based on the statistical finding for this survey, the outcome of the non-response bias analysis based on ethnicity in this research was found to be non-significant because $\mathrm{p}=0.017$ (less than 0.05 ). In other words, the finding revealed that "in two-tail test for non-response bias, no questions were found to have a significant statistical difference. Thus, the sample can be treated as a single data set as Non-response bias was not evident" (Mathews, 2011, p. 8). After completing the non-response bias analysis, the researcher will proceed to conduct common method variance analysis (Podsakoff et al., 2003; Chang et al., 2010)

Podsakoff, MacKenzie, Lee and Podsakoff (2003) as well as Bagozzi and Yi (1991) claimed that response bias could be one of the systematic measurements errors that creating suspicion on validity of the relationship between the constructs being estimated. In addition, the systematic error variance could lead to confounding empirical outcome and provide misleading conclusion (Campbell \& Fisk, 1959). Therefore, Podsakoff et al. (2003) suggested that the effect of common method variance on the outcome of the research study can be minimized by applying statistical methods known as Harman single-factor test. According to Podsaoff et al. (2003, p.889), "the Harman single-factor test requires loading all the measures in a study into an exploratory factor analysis, with the assumption that the presence of CMV is indicated by the emergence of either a single factor or general factor accounting for the majority of covariance among measures" and Harman single-factor test can be used as a diagnostic technique that "actually does nothing to statistically control for (or partial out) method effects". If common method bias is a problem, a single factor will account for most of the variance in the construct model, which may with variance more than 50\% (Podsaoff et al., 2003). Therefore, this research exploited the Harman's single-factor test to evaluate the common method bias. In order to detect the effect of common method variance on the outcome, the data was analyzed and taking all the items for factor extraction keeping the number of factors equal to 1 in the exploratory factor analysis via SPSS software operation. Based on the statistical finding in this research, the percentage of variance extracted for factor was $35.69 \%$ in which this figure was less than $50 \%$ rule of thumb. Therefore, the data does not provide the problem of common method bias in this research. The next section will assess the assumptions of normality.

Researcher should ensure that the distribution of responses is normally distributed before performing any statistical testing and analysis. According to Hair et al. (2010), normality can be referred to "the shape of data distribution for an individual metric variable and its correspondence to the normal distribution". The statistical tests for normality via AMOS software would be carried out. These statistical tests included skewness and kurtosis, Kolmogrove-Smirnov test, and Critical Ratio (as indicated in the Confirmatory Factor Analysis output). In addition, multicollinearity analysis would be evaluated in this research to assess the independence assumption of the normality distribution of the data. Besides, distribution of standardized residual will be evaluated to assess the multivariate normality in this research.

Based on the statistical output from the Kolmogrove-Smirnov test (KS test), the significant $\mathrm{p}$ value is 0.0001 in which the figure is less than 0.05 (the rule of thumb), it can be concluded that the collected data is significantly different from normal distribution. However, Field (2013) has warned that in large samples, Kolmogorov-Smirnov Statistic test can be significant even when the scores are only slightly different from a normal distribution. Therefore, it is recommended to interpret the results of Kolmogorov-Smirnov Statistic test in conjunction with the values of Skewness and Kurtosis (Field, 2013).

The evaluation of skewness and kurtosis is highly related to the degree of standard deviation. According to Howell (2013, p.41), the standard deviation is "defined as the positive square root of the variance" and it is generally applied to test the average deviation of all scores from the mean. Based on the figures of the standard deviation, a researcher has to learn the score standardization about a normal distribution because Gravetter and 
Wallnau (2013, p. 170) argued that the "Z-scores measure positions in a distribution in terms of standard deviation away from the mean". If a data is presented as a normal distribution, the data would be symmetrically distributed with the highest frequency locate at the central point and lower occurrences on each side. According to Allen, Bennett and Heritage (2014), the measure of test score's variability could be standardized by using z-test formula for Skewness and Kurtosis. In other words, a common rule of thumb for testing normality is to divide the values of skewness and kurtosis by the respective standard errors in order to obtain the z-scores for the skewness and kurtosis (ie., $Z_{\mathrm{s}}=$ Skewness/Standard Error, $Z_{\mathrm{k}}=$ Kurtosis/Standard Error). From the Table 2, the statistical finding disclosed that all the values of $Z_{s}$ and $Z_{k}$ are within the range of $|1.96|$. Since the values of both $Z_{\mathrm{s}}$ and $Z_{\mathrm{k}}$ are within the range of $|1.96|$ (which has a two-tailed probability), it indicates that the data of this study is approximately normally distributed (Allen \& Bennet, 2012).

Table 2. Descriptive of testing statistical on skewness and kurtosis

\begin{tabular}{ccccccccc}
\hline & Mean & Standard Deviation & \multicolumn{3}{c}{ Skewness } & \multicolumn{3}{c}{ Kurtosis } \\
\cline { 2 - 8 } & Statistic & Statistic & Statistic & Std. Error & Z-score & Statistic & Std. Error & Z-Score \\
\hline ABS1 & 3.27 & 0.798 & -.099 & .105 & -.943 & -.083 & .210 & -.395 \\
ABS2 & 3.35 & 0.813 & -.121 & .105 & -1.152 & -.040 & .210 & -.190 \\
ABS3 & 3.19 & 0.831 & -.120 & .105 & -.1 .143 & -.122 & .210 & -.581 \\
ABS4 & 3.21 & 0.848 & -.070 & .105 & -0.667 & -.078 & .210 & -.371 \\
ABS5 & 3.49 & 0.801 & -.059 & .105 & -0.562 & -.136 & .210 & -.648 \\
PRO_INN1 & 3.17 & 0.892 & .066 & .105 & 0.629 & -.190 & .210 & -0.905 \\
PRO_INN2 & 3.11 & 0.926 & -.110 & .105 & -1.048 & -.313 & .210 & -1.490 \\
PRO_INN3 & 3.36 & 0.739 & -.154 & .105 & -1.467 & -.226 & .210 & -1.076 \\
ORG_INN1 & 3.42 & 0.806 & -.120 & .105 & -1.142 & -.015 & .210 & -0.071 \\
ORG-INN2 & 3.33 & 0.805 & -.196 & .105 & -1.867 & -.085 & .210 & -.405 \\
ORG_INN3 & 3.32 & 0.746 & -.079 & .105 & -.752 & -.048 & .210 & -.229 \\
TEC_INN1 & 3.28 & 0.913 & -.101 & .105 & -.962 & -.246 & .210 & -1.171 \\
TEC_INN2 & 3.21 & 0.845 & -.057 & .105 & -.543 & -.187 & .210 & -0.890 \\
TEC_INN3 & 3.15 & 0.820 & .020 & .105 & -.190 & -.036 & .210 & -.171 \\
TEC_INN4 & 3.28 & 0.788 & -0.026 & .105 & -.248 & -.037 & .210 & -.176 \\
\hline
\end{tabular}

According to Hair et al. (2010), "the high correlation between independent variables can make problem in calculating the independent regression coefficients for the correlated independent variables" because the multicollinearity issues will not improve the independence assumption of the normality of the distribution. The multicollinearity analysis can be discovered from the values of Variance Inflation Factor (VIF) and Tolerance (TV) as indicated in Table 3.

Table 3. Statistical findings on multicollinearity analysis

\begin{tabular}{|c|c|c|c|c|c|c|c|c|c|c|c|}
\hline \multicolumn{12}{|c|}{ Coefficients $^{a}$} \\
\hline \multirow{2}{*}{\multicolumn{2}{|c|}{ Model }} & \multicolumn{2}{|c|}{ Unstandardized Coefficients } & \multirow{2}{*}{$\begin{array}{c}\begin{array}{c}\text { Standardized } \\
\text { Coefficients }\end{array} \\
\text { Beta }\end{array}$} & \multirow[b]{2}{*}{$t$} & \multirow[b]{2}{*}{ Sig. } & \multicolumn{3}{|c|}{ Correlations } & \multicolumn{2}{|c|}{ Collinearity Statistics } \\
\hline & & $\mathrm{B}$ & Std. Error & & & & Zero-order & Partial & Part & Tolerance & VIF \\
\hline \multirow[t]{4}{*}{1} & (Constant) & 2.335 & .517 & & 4.517 & .000 & & & & & \\
\hline & ORG13 & .220 & .045 & .202 & 4.914 & .000 & .420 & .208 & .175 & .750 & 1.332 \\
\hline & TEC14 & .317 & .033 & .401 & 9.653 & .000 & .527 & .386 & .344 & .736 & 1.358 \\
\hline & ABS15 & .061 & .026 & .090 & 2.345 & .019 & .285 & 101 & .084 & .861 & 1.161 \\
\hline
\end{tabular}

a. Dependent Variable: PR013

The finding from Table 3 showed the outcome of the multicollinearity analysis by evaluating the Tolerance Value 
and Variance Inflation Factor (VIF): the value for Variance Inflation Factor (VIF) for all the constructs were less than 5.0 [rule of thumb as indicated by Hair et al. (2010)] in which the range of VIF in the finding was ranging from 1.161 to 1.358; while the values of Tolerance for the independent constructs were more than 0.1 [rule of thumb as indicated by Hair et al. (2010)] in which the Tolerance Values in the finding was ranging from 0.731 to 0.861. The findings of tolerance values and VIF of the present study showed that there is no problem for the multicollinearity. Therefore, the independence assumption of the normality test can be identified based on the multicollinearity analysis.

According to Diamnantopoulos and Vrontos (2010), multivariate normality can be evaluated by examining the distribution of standardized residual. Tabachnick and Fidell (2001) stated that residuals in the context of Structure Equation Modelling are residual covariance. Hair et al. (2010) stated that standardized residual (SR) can be directly comparable and the values of standardized residual can be in the form of positive and negative. According to the rule of thumb proposed by Hair et al. (2010), the values of standardized residual between $|2.5|$ and $|4.0|$ deserve some attentions because the value indicates that it may be need to perform changes in the measurement model due to the problems associate with items. Based on the statistical output of the AMOS in Figure 2, the highest values of standardized residual can be notified between ORG_INN 1 and ABS 1(-1.493) and ORG_INN and PRO_INN 1(-1.355) respectively. These values are far below the rule of thumb. In conclusion, the finding from the standardized residuals indicates that the data is normally distributed.

Standardized Residual Covariances (Group number 1 - Default model)

ABS5 ABS4TEC_INN4 ORG_INN1ORG_INN2ORG_INN3 TEC_INN1 TEC_INN2TEC_INN3 PRO_INN3 PRO_INN2PRO_INN1 ABS3 ABS2 ABS1

ABS5 $\quad .000$

$\begin{array}{lrr}\text { ABS4 } & .000\end{array}$

TEC_INN4 $\quad-.020-.239 \quad .000$

ORG INN1 $\quad \begin{array}{llll}.152 & -.269 & -.055 & .000\end{array}$

ORG INN2 $\quad .538-1.083 \quad 1.259 \quad .198$

ORG_NN3 $1.056-.543 \quad 583 \quad .110 \quad-.170 \quad .000$

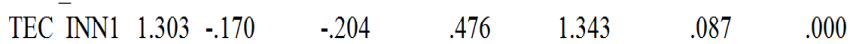

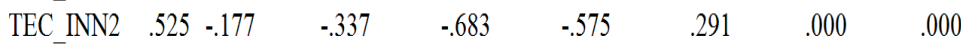

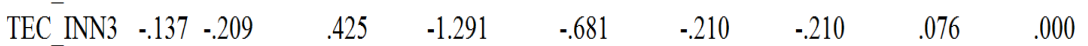

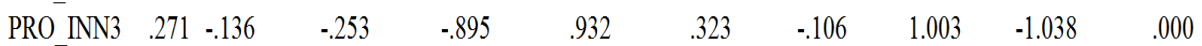

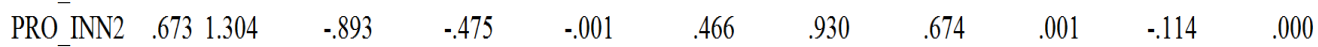

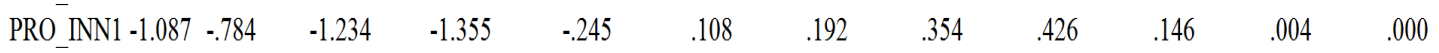

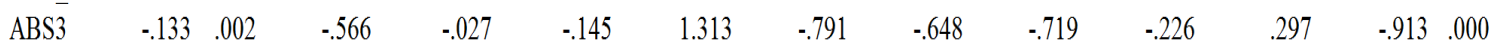

$\begin{array}{lllllllllllll}\text { ABS2 } & -.352 & .167 & .638 & .116 & .696 & .767 & 1.187 & 1.407 & .444 & .424 & -.101 & -.074-.181 .000\end{array}$

$\begin{array}{llllllllllllllll}\text { ABS1 } & .007 & -.268 & -.515 & -1.493 & .032 & -1.023 & .708 & -.052 & -.010 & .644 & -.455 & -.677 & .463 & .000 & .000\end{array}$

Figure 2. Standard residual for measurement model

\subsection{Descriptive Analysis}

A total of 600 sets of questionnaire were distributed to the respondents in the survey and there was a total of 543 usable questionnaires could be used in the data analysis. Therefore, the response rate in this research is $90.5 \%$. The respondent's demographic profile was classified into four types, including gender, age, and ethnicity and education level. The descriptive statistics revealed that there were 291 male $(53.6 \%)$ and 252 female (46.6\%) respondents took part in this survey. In terms of the age distribution, majority of the respondents is within the age group of 20-23 years old that representing 90.7\% (487) of the sample. For the Ethnicity attainment of the respondents, 497 respondents are Chinese, representing $92.6 \%$ of the samples. In related to the educational attainment of respondents, majority of the respondents are undergraduate degree holders that constitute 420 respondents $(78.2 \%)$ of the samples. The demographic configuration of this study was presented in Table 4. 
Table 4. Demographic composition of main test respondents

\begin{tabular}{lll}
\hline Demographic Feature & Frequency $\mathrm{n}=543$ & Percentage of Respondents \\
\hline Gender & 291 & Male $-53.6 \%$ \\
Age & 252 & Female $-46.4 \%$ \\
& 41 & Below 20 years old $-7.6 \%$ \\
Ethnicity & 487 & $20-23$ years old $-90.7 \%$ \\
& 7 & 23 years old above $-1.3 \%$ \\
& 497 & Chinese $-92.6 \%$ \\
Educational Level & 1 & Malay $-1.5 \%$ \\
& 27 & Indian $-5.0 \%$ \\
& 5 & Other- $0.9 \%$ \\
& 108 & SPM / UEC / STPM / Foundation on the year / Equivalent $-0.2 \%$ \\
& 420 & Diploma- $20.1 \%$ \\
& 1 & Degree- $-78.2 \%$ \\
\hline
\end{tabular}

\subsection{Scales Measurement}

\subsubsection{Reliability}

Reliability is one of the important scale measurement methods to evaluate the internal consistency and stability of the items or indicators for the respective constructs. Hair et al. (2010) asserted that internal consistency of the scales (referring to the Cronbach Alpha Coefficient) have to be more than 0.70 for the internal consistency to be assumed. Based on the statistical finding in Table 5, all the constructs in this study were represented with good reliability values more than 0.70 (Cavana et al., 2001) and this indicated high internal consistency and stability among their items in measuring the constructs.

Table 5. Reliability coefficient of the items in main study

\begin{tabular}{ccc}
\hline Construct & Cronbrach Alpha & Ranking \\
\hline ABS & 0.851 & Very Good \\
PRO_INN & 0.822 & Very Good \\
ORG_INN & 0.794 & Good \\
TEC_INN & 0.833 & Very Good \\
\hline
\end{tabular}

\subsubsection{Confirmatory Factory Analysis (CFA)}

In the structural equation modelling, confirmatory factor analysis is also known as measurement model. Before assessing the validity of the measurement model, the proposed conceptual model needs to be evaluated for fit with the data by conducting Goodness-of-fit (GOF) indices measurement. GOF presented how well the model reproduces the covariance matrix among the indicator items (Hair et al., 2010). Hair et al. (2010) claimed that what GOF can show itself by comparing theory to reality, which is completed by evaluating the similarity of the estimated covariance matrix with observed covariance matrix. In other words, the objective of assessing the measurement model validity is to evaluate the GOF and construct validity of the model (Hair et al., 2010). As proposed by Hair et al. (2010), three GOF tools will be employed in this research, including the absolute fit measures, incremental fit measures and parsimonious fit measure. The GOF of data for the model in this research is shown in Table 6. The data of GOF indicated that the $\mathrm{X}^{2}=122.988, \mathrm{P}=0.004$, while the goodness of fit indicators presented acceptable fit $\mathrm{X}^{2} / \mathrm{df}=1.46, \mathrm{GFI}=0.971, \mathrm{CFI}=0.998, \mathrm{AGFI}=0.958, \mathrm{RMSEA}=0.029$ and $\mathrm{AIC}=194.988$. All fit indices meet the guidelines of the cut off value, it can be concluded that the model fit is accepted. 
Table 6. Results of goodness-of-fit test for measurement model

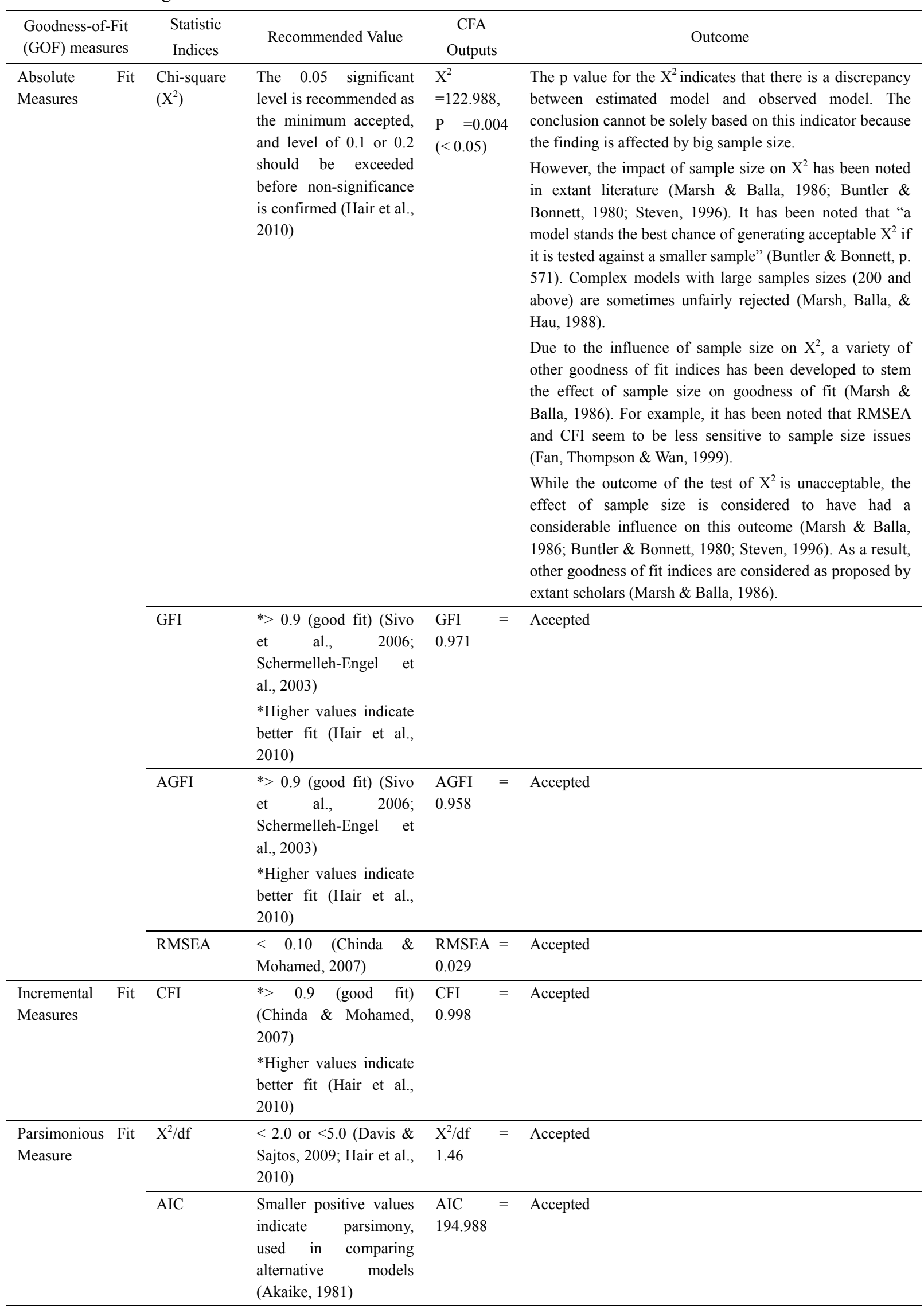


After completing the goodness of fit test, the construct validity in the measurement model will be carried out in the study. Figure 3 illustrates the final measurement model for this research.

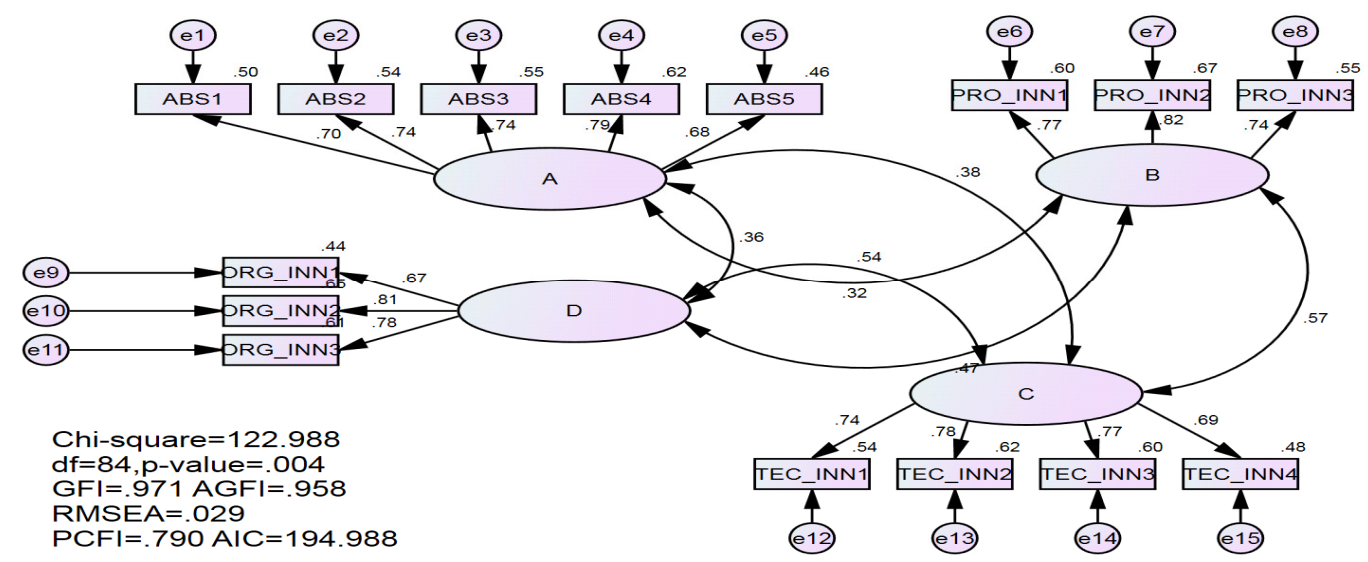

Figure 3. Final measurement model

The standardized estimates of AMOS output for the measurement model is indicated in Table 7 that displaying the factor loadings and the critical t-Value for each item. Bagozzi and Yi (2006) suggested that the estimates should be more than 0.60 cut-off value. However, Hair et al. (2010) asserted that internal consistency of the scales (referring to the Cronbach Alpha Coefficient) have to be more than 0.70 for the internal consistency to be assumed. Hair et al. (2006) also suggested that the critical t-value should be more than 1.96 cut-off values. The tvalue from AMOS text output is the critical ratio (C.R.), which provided the parameter estimate divided through its standard error (Arbuckle, 2007; Lu et al., 2007). The construct reliability estimates presented in this research indicated that all the values were more than 0.7 . The outputs for the factor loading, AVE and construct reliability confirmed adequate convergent validity of the constructs in the model. Moreover, the indicator items were all remained and adequate convergent validity has been created.

Table 7. Output of the final measurement model

\begin{tabular}{|c|c|c|c|c|}
\hline Constructs & Items & $\begin{array}{l}\text { Factor } \\
\text { Loadings }\end{array}$ & T-Values & $\mathrm{CR}$ \\
\hline \multicolumn{4}{|c|}{ Absorptive Capacity $(\mathrm{ABS}=\mathrm{A})$} & 0.906 \\
\hline ABS1 & $\begin{array}{l}\text { I can access more knowledge delivered by my University than } \\
\text { those students that study in other tertiary institution. }\end{array}$ & 0.687 & $* *$ & \\
\hline $\mathrm{ABS} 2$ & $\begin{array}{l}\text { I have a higher ability to search for the knowledge offered by } \\
\text { my University. }\end{array}$ & 0.721 & 15.316 & \\
\hline ABS3 & $\begin{array}{l}\text { I have a higher ability to identify value of external knowledge } \\
\text { offered by my university. }\end{array}$ & 0.746 & 14.553 & \\
\hline ABS4 & $\begin{array}{l}\text { I have a higher ability to predict the future development of the } \\
\text { core knowledge offered by my University. }\end{array}$ & 0.795 & 15.184 & \\
\hline ABS5 & $\begin{array}{l}\text { My knowledge comes from transferring or learning from } \\
\text { outside the University. }\end{array}$ & 0.686 & 13.621 & \\
\hline \multicolumn{4}{|c|}{ Product Innovation (PRO_INN =B) } & 0.891 \\
\hline PRO_INN1 & $\begin{array}{l}\text { The rate of product innovation into the University among } \\
\text { innovation activities is the highest over the last three years. }\end{array}$ & 0.772 & $* *$ & \\
\hline PRO_INN2 & $\begin{array}{l}\text { I describe my University as a University that focusing on } \\
\text { product/service innovation. }\end{array}$ & 0.821 & 17.075 & \\
\hline PRO_INN3 & $\begin{array}{l}\text { My University has the ability to work more effectively by } \\
\text { adopting new technologies. }\end{array}$ & 0.741 & 16.037 & \\
\hline
\end{tabular}


Technological Innovation (TEC_INN=C)

TEC_INN1 The rate of process innovation into the University among 0.700 innovation activities is the highest over the last three years.

TEC_INN2 I describe my University as a university that focusing on 0.753 process innovation.

TEC_INN3 The University of new processes are often perceived as very 0.793 novel by the students.

TEC_INN4 My University makes use of external technology to spearhead 0.707 the innovation process.

Organizational Innovation $(\mathrm{ORG}$ _INN=D)

ORG_INN1 In general, in recent years, there have been major changes in 0.666 the University's organization structure.

ORG_INN2 University makes every innovation effort to include staff from 0.806 a range of backgrounds.

ORG_INN3 Recent years have witnessed major innovation in the way the 0.779 University is run, in communication and marketing, and in relations with visitors.

** Means item was fixed for scaling purposes; therefore t-values are not available.

The discriminant validity measurement is evaluated to make sure the indicator items are distinct from others (Campbell \& Fiske, 1959; Anderson \& Gerbeng, 1988; Bago \& Yi, 1998; Sekaran, 2003; Cooper \& Schindler, 2006; Hair et al., 2010). Hair et al. (2010) advocated that in order to create discriminant validity, researcher needs to compare the value of average variance extracted (AVE) and squared inter-construct correlation (SIC) in CFA. Table 8 shows the output of the comparison between the average variance extracted (AVE) and squared inter-construct correlation (SIC), it can be found that all the AVE estimates are higher than the corresponding SIC. In other word, it means that there is more commonality within indicator items (constructs) than there are within other indicator items (constructs). Therefore, the result can be concluded that the four constructs in the model indicates discriminant validity.

Table 8. Comparison of AVE with SIC by Construct

\begin{tabular}{lllll}
\hline Constructs & $\mathrm{A}$ & $\mathrm{B}$ & $\mathrm{C}$ & $\mathrm{D}$ \\
\hline $\mathrm{A}$ & $0.906^{*}$ & $0.100^{* *}$ & $0.147^{* *}$ & $0.134^{* *}$ \\
$\mathrm{~B}$ & $0.100^{* *}$ & $0.891^{*}$ & $0.324^{* *}$ & $0.2243^{* *}$ \\
$\mathrm{C}$ & $0.174^{* *}$ & $0.324^{* *}$ & $0.893^{*}$ & $0.300^{* *}$ \\
$\mathrm{D}$ & $0.134^{* *}$ & $0.224^{* *}$ & $0.300^{* *}$ & $0.871^{*}$ \\
\hline
\end{tabular}

Note: $\mathrm{A}=$ Absorptive Capacity; $\mathrm{B}=$ Product innovation; $\mathrm{C}=$ Technological innovation; $\mathrm{D}=$ Organizational innovation. *indicates AVE; **indicates SIC

According to Hair et al. (2010, p.710), "nomological validity is tested by examining whether the correlations among the constructs in a measurement theory make sense and the matrix of construct correlations can be careful in this assessment". In the CFA, the construct correlations are applied to evaluate the nomological validity (Hair et al., 2010). The output of the nomological validity for this study is displayed in Table 9. By testing a measurement theory that applying constructs in which being measured through multi-item scales that developed in the previous section of this research, it is expected that there would be positive relationships among the constructs (Hair et al., 2010). Table 9 presented that all the relationships among the constructs were significant and positively related. The result concluded that there was an acceptable nomological validity in the measurement model. 
Table 9. Correlations between constructs

\begin{tabular}{ccc}
\hline Relationship & Estimate & P-Value \\
\hline B $<->$ C & 0.569 & $* * *$ \\
C<-D & 0.545 & $* * *$ \\
B $<->$ D & 0.473 & $* * *$ \\
A $<->$ B & 0.317 & $* * *$ \\
A $<->$ D & 0.366 & $* * *$ \\
A $<->$ C & 0.384 & $* * *$ \\
\hline
\end{tabular}

** Significant at 0.01 level (two-tailed)

***Significant at 0.001 level (two-tailed)

Note: $\mathrm{A}=$ Absorptive Capacity; $\mathrm{B}=$ Product innovation; $\mathrm{C}=$ Technological innovation; $\mathrm{D}=$ Organizational innovation

\subsection{Inferential Analysis}

\subsubsection{Structural Model}

After concluding the measurement model, structural model was developed to test the hypothesized relationships. Figure 4 presents the output of the structural model.

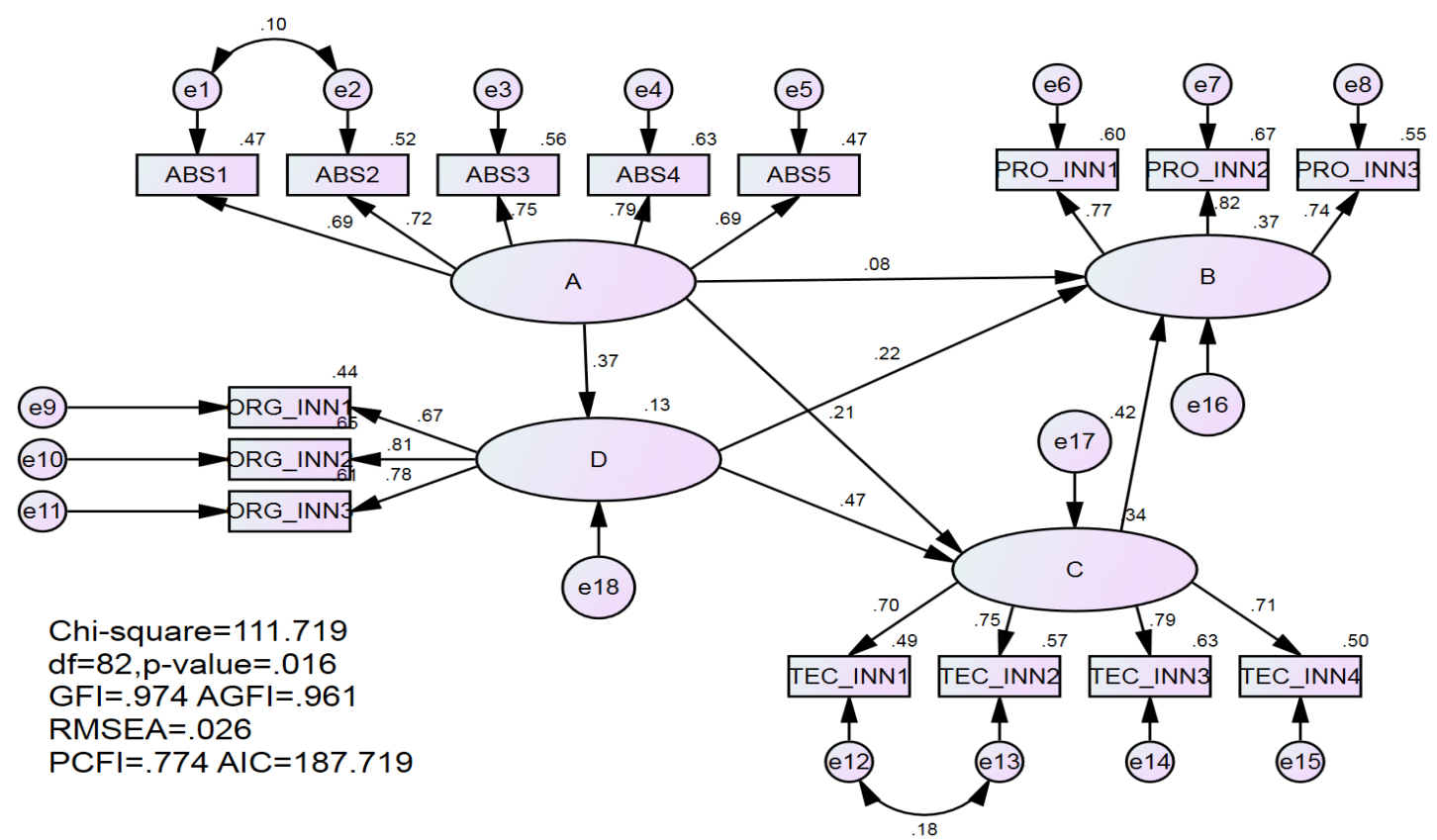

Note: $\mathrm{A}=$ Absorptive Capacity; $\mathrm{B}=$ Product innovation; $\mathrm{C}=$ Technological innovation; $\mathrm{D}=\mathrm{Organizational}$ innovation

Figure 4. Overall estimate model output

Table 10 indicates the Goodness-of-Fit Test for the structural model in which the structural model is adopted in testing the proposed hypothetical relationships in this study. The output of goodness of fit for the structural model are $\mathrm{X}^{2}=111.719, \mathrm{p}<0.016, \mathrm{X}^{2} / \mathrm{df}=1.362$, GFI $=0.974, \mathrm{AGFI}=0.961, \mathrm{CFI}=0.991, \mathrm{RMSEA}=0.026$, and $\mathrm{AIC}=187.719$. The results of the goodness of fit in related to this estimated structural model are perfectly fit into the rule of thumbs as provided in Table 10. 
Table 10. The results of goodness-of-fit test for structural model

\begin{tabular}{|c|c|c|c|c|}
\hline $\begin{array}{l}\text { Goodness-of-Fit } \\
\text { (GOF) } \\
\text { measures }\end{array}$ & Statistic & Recommended Value & Findings & Outcome \\
\hline \multirow[t]{6}{*}{$\begin{array}{l}\text { Absolute } \\
\text { Measures }\end{array}$} & $\mathrm{X}^{2}$ & $\begin{array}{l}\text { The } 0.05 \text { significant } \\
\text { level is } \\
\text { recommended as the } \\
\text { minimum accepted, } \\
\text { and level of } 0.1 \text { or } \\
0.2 \text { should be } \\
\text { exceeded before } \\
\text { non-significance is } \\
\text { confirmed (Hair et } \\
\text { al., 2006) }\end{array}$ & $\begin{array}{l}X^{2}=111.719 \\
p<0.016\end{array}$ & $\begin{array}{l}\text { The } \mathrm{p} \text { value for the } \mathrm{X}^{2} \text { indicates that there is a discrepancy } \\
\text { between estimated model and observed model. The } \\
\text { conclusion cannot be solely based on this indicator because } \\
\text { the finding is affected by big sample size. } \\
\text { However, the impact of sample size on } \mathrm{X}^{2} \text { has been noted in } \\
\text { extant literature (Marsh \& Balla, 1986; Buntler \& Bonnett, } \\
\text { 1980; Steven, 1996). Complex models with large sample } \\
\text { sizes ( } 200 \text { and above) are sometimes unfairly rejected } \\
\text { (Marsh, Balla \& Hau, 1988). Due to the influence of sample } \\
\text { size on } \mathrm{X}^{2} \text {, a variety of other goodness of fit indices has } \\
\text { been developed to stem the effect of sample size on } \\
\text { goodness of fit (Marsh \& Balla, 1986). As a result, other } \\
\text { goodness of fit indices are considered as proposed by extant } \\
\text { scholars (Marsh \& Balla, 1986). }\end{array}$ \\
\hline & $\mathrm{X}^{2} / \mathrm{df}$ & $\begin{array}{l}<2.0-<5.0 \text { (Hair et } \\
\text { al., 2006; Davis \& } \\
\text { Sajtos, 2009) }\end{array}$ & $\mathrm{X}^{2} / \mathrm{df}=1.362$ & Accepted \\
\hline & GFI & $\begin{array}{l}\text { *> } 0.9 \text { (good fit) } \\
\text { (Sivo et al., 2006; } \\
\text { Schermelleh-Engel et } \\
\text { al., 2003) } \\
\text { *Higher values } \\
\text { indicate better fit } \\
\text { (Hair et al., 2006) }\end{array}$ & $\mathrm{GFI}=0.974$ & Accepted \\
\hline & AGFI & $\begin{array}{l}\text { *> } 0.9 \text { (good fit) } \\
\text { (Sivo et al., 2006; } \\
\text { Schermelleh-Engel et } \\
\text { al., 2003) } \\
\text { *Higher values } \\
\text { indicate better fit } \\
\text { (Hair et al., 2006) }\end{array}$ & $\mathrm{AGFI}=0.961$ & Accepted \\
\hline & RMSEA & $\begin{array}{l}<0.10 \text { (Chinda \& } \\
\text { Mohamed, 2007) }\end{array}$ & RMSEA $=0.026$ & Accepted \\
\hline & RMR & $\begin{array}{l}<0.05 \quad(\mathrm{Wu}, \quad 1996 ; \\
\text { Hair, et al, 2010) }\end{array}$ & $\mathrm{RMR}=0.018$ & Accepted \\
\hline \multirow[t]{5}{*}{$\begin{array}{l}\text { Incremental Fit } \\
\text { Measures }\end{array}$} & CFI & $\begin{array}{l}*>0.9 \text { (good fit) } \\
\text { (Chinda } \\
\text { Mohamed, 2007) } \\
\text { *Higher values } \\
\text { indicate better fit } \\
\text { (Hair et al., 2006) }\end{array}$ & $\mathrm{CFI}=0.991$ & Accepted \\
\hline & NFI & $\begin{array}{l}>0.90 \quad(\mathrm{Wu}, \quad 1996 ; \\
\text { Hair et al., 2010) }\end{array}$ & 0.967 & Accepted \\
\hline & RFI & $\begin{array}{l}>0.90 \quad(\mathrm{Wu}, \quad 1996 ; \\
\text { Hair et al., 2010) }\end{array}$ & 0.958 & Accepted \\
\hline & IFI & $\begin{array}{l}>0.90 \quad(\mathrm{Wu}, \quad 1996 ; \\
\text { Hair et al., 2010) }\end{array}$ & 0.991 & Accepted \\
\hline & $\begin{array}{l}\text { TLI } \\
\text { (NNFI) }\end{array}$ & $\begin{array}{l}>0.90 \quad(\mathrm{Wu}, \quad 1996 ; \\
\text { Hair et al., 2010) }\end{array}$ & 0.988 & Accepted \\
\hline \multirow[t]{2}{*}{$\begin{array}{l}\text { Parsimonious } \\
\text { Fit Measure }\end{array}$} & PGFI & $\begin{array}{l}>0.5(\mathrm{Wu}, 1996 \text {; Hair } \\
\text { et al., 2010) }\end{array}$ & 0.665 & Accepted \\
\hline & PNFI & $\begin{array}{l}>0.5 \text { (Wu, 1996; Hair } \\
\text { et al., 2010) }\end{array}$ & 0.755 & Accepted \\
\hline
\end{tabular}




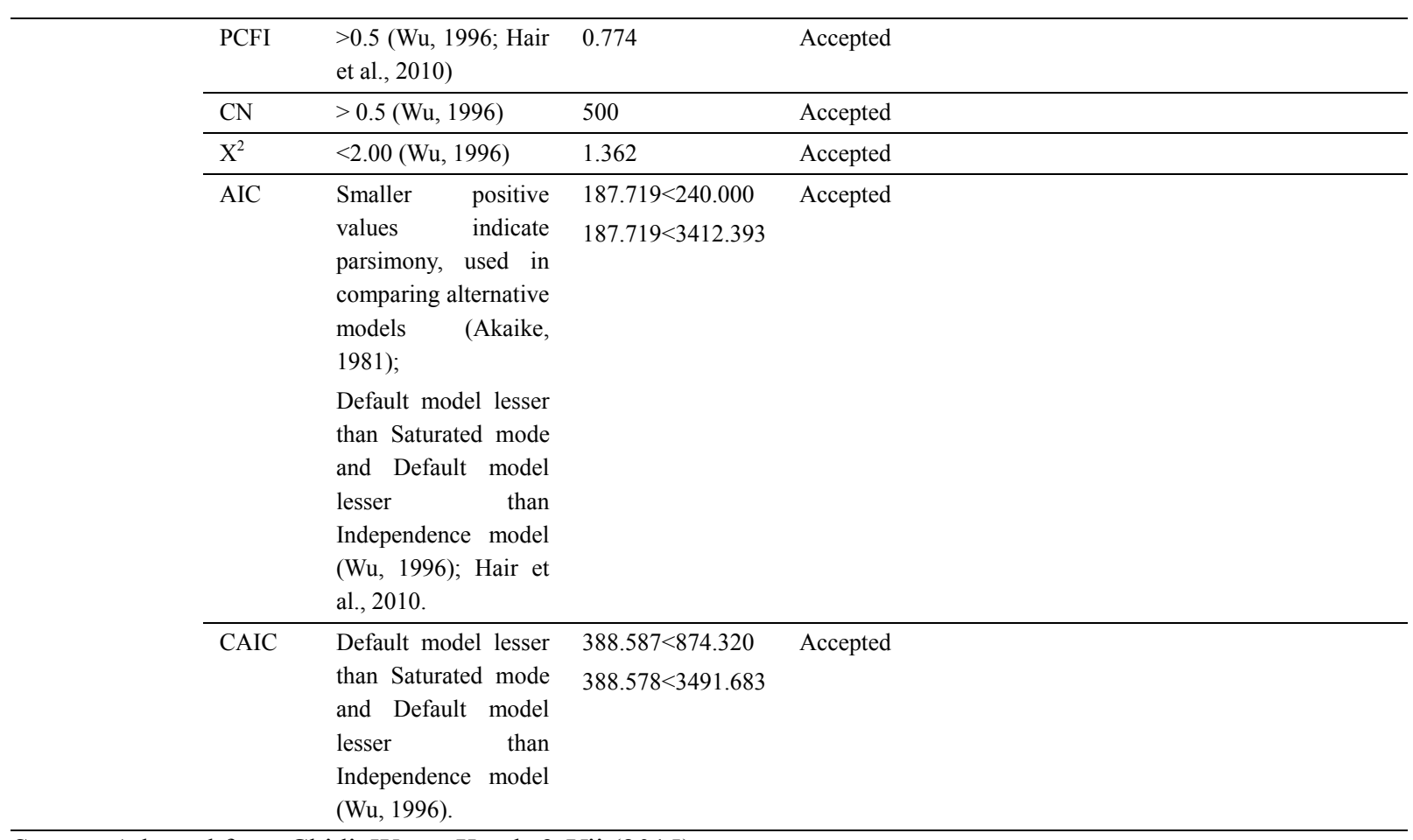

Source: Adapted from Chidi, Wang, Kwek \& Yii (2015)

\subsubsection{Inferential Analysis - Hypotheses Testing}

\subsubsection{Direct Relationship}

After assessing the Goodness of Fit Test for the structural model, inferential analysis will be adopted to validate the hypotheses and draw inferences from the findings of a study (Adeymi, 2009; Baddie \& Halley, 1995; Kolawole, 2001). A total of six direct hypothesized relationships (H1, H2, H3, H5, H6 and H8) were tested in this research. The outcomes of these six direct relationships were generated from the estimated output of the structural model. The level of significance for the relationships was based on two tailed $Z$ tests with $\alpha=0.05$ and C.R. $=1.96$ that has been known to be applied as the threshold in the extant literature (Fisher, 1935; Goodman, 1999; Lewis-Beck, Bryman, \& Liao, 2004). Furthermore, this significance level is selected to indicate that the outcome is extremely adequate to have a $95 \%$ probability of appearing if the null hypothesis is not false. According to Noymer (2008), this level of significance was selected because it has been found in social sciences that the conventional cut-off point is 0.05 . The results of the direct hypothesized relationships were presented in Table 11. All the six direct hypothesized relationships were supported in this research.

Table 11. Significance of construct relationships

\begin{tabular}{ccccccc}
\hline Hypothesis & Relationship & Estimate & S.E & C.R & P & Standardized Estimate \\
\hline H1 & C->B & 0.448 & 0.067 & 6.654 & $* * *$ & 0.423 \\
H2 & D->B & 0.255 & 0.072 & 3.545 & $* * *$ & 0.235 \\
H3 & D->C & 0.522 & 0.063 & 8.239 & $* * *$ & 0.467 \\
H5 & A->B & 0.132 & 0.060 & 2.203 & $* * *$ & 0.106 \\
H6 & A->C & 0.253 & 0.061 & 4.123 & $* * *$ & 0.213 \\
H8 & A->D & 0.388 & 0.058 & 6.706 & $* * *$ & 0.366 \\
\hline
\end{tabular}

***Significant at 0.001 level (two-tailed)

Note: $\mathrm{A}=$ Absorptive Capacity; $\mathrm{B}=$ Product innovation; $\mathrm{C}=$ Technological innovation; $\mathrm{D}=\mathrm{Organizational}$ innovation 


\subsubsection{Mediated Relationship}

For the purpose of testing four hypothesized mediating relationship (H4, H7, H9 and H10), indirect and direct effects were computed by applying a bootstrapping feature that unique to the AMOS software. Thus, AMOS output would present the outcomes of the indirect and direct effects. During the setting up of "bootstrap" tab, "perform bootstrap" was setting in 5000 sub-sample randomly selected from the data and "Bias-corrected confidence intervals" is checked for $95 \mathrm{BC}$ confidence level. In this manner, the direct, indirect and total effects were generated along with the standard error estimates and significance levels. According to Preacher and Hayes (2008), a bootstrapped confidence interval for the indirect effect was gathered by applying relevant procedures. Based on Cheung and Lau (2008) argument, mediation was measured by applying the bias-corrected bootstrap because it was acknowledged in providing better statistical power. Moreover, Preacher and Hayes (2008, p.880) stated that bootstrapping is a nonparametric resampling procedure "that does not impose the assumption of normality of the sampling distribution" and the bootstrapping was advocated to be adopted in testing the mediation effect. Therefore, Preacher and Hayes (2008) argued that the mediation effect is significant when the mediation adopts with $\mathrm{n}=5000$ bootstrap resamples and the bias-corrected confidence interval (95\%) does not include zero. The direct and indirect effects in the structural model that included mediating relationships were shown in the Tables 12, 13 and 14 that corresponding to their respective hypotheses. All the three tables indicated the output of the mediation effects for the relevant hypotheses (H4, H7, H9 and H10).

Table 12. Results of mediation effect in the computing model

\begin{tabular}{lll}
\hline Hypothesis & Hypothesis Relationship & Mediating Impact \\
\hline H4 & D->C->B & Median $(0.198>0.085)$ (Hair \& Anderson, 2006) \\
H7 & A->D->C & Median $(0.171>0.085)$ (Hair \& Anderson, 2006) \\
H9 & A->C->B & Median $(0.09>0.085)$ (Hair \& Anderson, 2006) \\
H10 & A->D->B & Median $(0.086>0.085)$ (Hair \& Anderson, 2006) \\
\hline
\end{tabular}

Note: $\mathrm{A}=$ Absorptive Capacity; $\mathrm{B}=$ Product innovation; $\mathrm{C}=$ Technological innovation; $\mathrm{D}=$ Organizational innovation

Table 13. Results of direct and indirect effects analyses

\begin{tabular}{lllllllllllllll}
\hline & \multicolumn{3}{c}{ Standardized Total Effect } & \multicolumn{4}{c}{$\begin{array}{l}\text { Standardized } \\
\text { Direct Effect (DE) }\end{array}$} & \multicolumn{5}{c}{$\begin{array}{l}\text { Standardized } \\
\text { Indirect Effect (IE) }\end{array}$} \\
\hline & \multicolumn{1}{l}{} & \multicolumn{1}{c}{ A } & D & C & B & A & D & C & B & A & D & C & B \\
D & 0.366 & 0.000 & 0.000 & 0.000 & 0.366 & 0.000 & 0.000 & 0.000 & 0.000 & 0.000 & 0.000 & 0.000 \\
C & 0.384 & 0.467 & 0.000 & 0.000 & 0.213 & 0.467 & 0.000 & 0.000 & 0.171 & 0.000 & 0.000 & 0.000 \\
B & 0.347 & 0.413 & 0.423 & 0.000 & 0.106 & 0.235 & 0.423 & 0.000 & 0.241 & 0.197 & 0.000 & 0.000 \\
\hline
\end{tabular}

Note: $\mathrm{A}=$ Absorptive Capacity; $\mathrm{B}=$ Product innovation; $\mathrm{C}=$ Technological innovation; $\mathrm{D}=$ Organizational innovation

Table 14. Results of bootsraping tab-standardized indirect effects-two tailed significance (PC)

\begin{tabular}{ccc}
\hline $\begin{array}{c}\text { Direct Hypothesis } \\
\text { Relationship }\end{array}$ & $\begin{array}{c}\text { Standardized Direct Effects-Lower } \\
\text { Bounds }\end{array}$ & $\begin{array}{c}\text { Standardized Direct Effects-Lower } \\
\text { Bounds }\end{array}$ \\
\hline A->D & 0.264 & 0.459 \\
A->C & 0.108 & 0.319 \\
A->B & 0.029 & 0.175 \\
D->C & 0.358 & 0.564 \\
D->B & 0.079 & 0.338 \\
C->B & 0.281 & 0.553
\end{tabular}




$\begin{array}{ccc}\text { Relationship } & \text { Bounds } & \text { Bounds } \\ \text { A->C } & 0.114 & 0.238 \\ \text { A->B } & 0.180 & 0.317 \\ \text { D->B } & 0.124 & 0.287\end{array}$

The $95 \%$ confidence interval for the standardized Indirect (mediated) effect value does not include zero

(Preacher \& Hayes, 2008), in which zero does not fall within the range of lower and upper bounds.

\begin{tabular}{|c|c|c|}
\hline \multicolumn{3}{|c|}{ Standardized Indirect Effect-Two Tailed Significance (PC) } \\
\hline$A->C$ & 0.000 & $\begin{array}{l}\text { The standardized indirect (mediated) effect of } \mathrm{A} \text { on } \mathrm{C} \text { is significantly different } \\
\text { from zero at the } 0.001 \text { level ( } \mathrm{p}=0.000 \text { two-tailed). }\end{array}$ \\
\hline$A->B$ & 0.000 & $\begin{array}{l}\text { The standardized indirect (mediated) effect of A on B is significantly different } \\
\text { from zero at the } 0.001 \text { level ( } \mathrm{p}=0.000 \text { two-tailed). }\end{array}$ \\
\hline $\mathrm{D}->\mathrm{B}$ & 0.000 & $\begin{array}{l}\text { The standardized indirect (mediated) effect of } \mathrm{D} \text { on } \mathrm{B} \text { is significantly different } \\
\text { from zero at the } 0.001 \text { level ( } \mathrm{p}=0.000 \text { two-tailed). }\end{array}$ \\
\hline
\end{tabular}

Note: $\mathrm{A}=$ Absorptive Capacity; $\mathrm{B}=$ Product innovation; $\mathrm{C}=$ Technological innovation; $\mathrm{D}=$ Organizational innovation

From Table 14, it can be discovered that the results of the direct relationships proved significant for all the six hypothesized direct relationships. In terms of indirect relationship, those 4 indirect relationships showed partial mediation because the results of mediating impact are more than 0.085 (Hair \& Anderson, 2006), the 95\% confidence interval for the indirect effect of value does not include zero (Preacher \& Hayes, 2008) which means zero does not fall within the range between standardized indirect effects-lower bounds and standardized indirect effects -upper bounds $(0.114$ to $0.238 ; 0.180$ to $0.317 ; 0.124$ to 0.187$)$. After confirming the results of the relationships, the study concluded that: (1) organization innovation (D) is a partial mediator in the relationship between absorptive capacity (A) and technological innovation (C); (2) organizational innovation (D) is a partial mediator in the relationship between absorptive capacity (A) and product innovation (B); (3) technological innovation (C) is a partial mediator in the relationship between absorptive capacity (A) and product innovation (B); (4) technological innovation (C) is a partial mediator in the relationship between organizational innovation (D) and the product innovation (B).

\section{Conclusion}

\subsection{Implication of the Research}

These research findings carried out several implications for the different stakeholders. The implications of this research can be elaborated based on both theoretical implication and managerial implication.

\subsubsection{Theoretical Implication}

Although a lot of studies in related to the innovation have been carried out in the extant literature (Dodgson, 1993; Hagedoorn, 2002; Deeds \& Rothaermel, 2003; Faems et al., 2005; Schilling \& Phelps, 2007; Eisingerich et al., 2009), the extended research concerning the interactive relationship among various types of innovation and absorptive capacity are not well articulated. Based on the empirical study from this research, the study concludes the following hypotheses: (1) Technological innovation mediates the relationship between organizational innovation and product innovation; (2) Technological innovation mediates the relationship between absorptive capacity and product innovation; (3) Organizational innovation mediates the relationship between absorptive capacity and technological innovation; and (4) Organizational innovation mediates the relationship between absorptive capacity and product innovation.

\subsubsection{Managerial Implication}

Although there is a wide body of research on product innovation, still there is lack of evidences about the effects of these concepts on product innovation. This research has tried to highlight those gaps and bridge the study empirically. This research has significant practical implications for most of the Malaysia organizations in particularly to the tertiary education providers. In order to transfer knowledge into actions and obtain better innovation, organizations may require to grasp the major characteristics of their knowledge and to find out the level of absorptive capacity of their organizations. For the organization with high degree of absorptive capacity, its innovation is much depended on the effectiveness of the organisation to acquire, assimilate, transfer and 
exploit the required knowledge and capacity. Effectiveness of absorptive capacity will enable the company to increase its technology innovation, organisational innovation and product innovation. Therefore, the company shall concentrate to allocate relevant resources in these related areas for the purpose of improving the overall innovation efforts.

\subsection{Research Limitation}

Some limitations in this research need to be highlighted. This research only applied quantitative methodology in the cross-sectional study to investigate the relationships among absorptive capacity, technological innovation, organizational innovation and product innovation. The insight of the phenomenon needs to be investigated besides assessing their relationships. In addition, this research did not evaluate the innovation based on the cross cultural setting that encompasses various industries. Therefore, this study will not able to provide the insight of the innovation from the cross-industries and cross-cultural perspectives.

\subsection{Recommendations for Further Research}

In resolving the research limitations as above, several recommendations are suggested for the future research. According to Damanpour and Gopalakrishnan (2001, pp. 47-48), product innovation is required to comply with the changing of the market needs from time to time. Therefore, cross-sectional study may not able to portray the observed change in patterns and the causality of the organization's product innovation (Easterby-Smith et al., 2003). The adoption of longitudinal study is highly recommended in the future research because the longitudinal study can grasp the temporal dynamics of perception change that affect the determinants of the organization's product innovation, and which can help researchers to recognize the cause and effect relationships between the various constructs (Cavana, et al., 2001). On the other hand, it may need to conduct a qualitative research to gain the insights of the innovation in the cross-cultural and cross-industries perspective.

\section{References}

Aljanabi, A. Q. R. A., Noor, N. A. M., \& Dileep Kumar, M. (2014). The mediating role of absorptive capacity in its effect on organizational support factors and technological innovation. Information Management and Business Review, 6(1), February, 25-41.

Abernathy W. J., \& Clark, K. B. (1985). Innovation: mapping the winds of creative destruction. Research Policy, 14, 3-22.

Aike, H. (1981). Likelihood of a model and information criteria. Journal of Econometrics, 16, 3-14.

Alegre, J., Chiva, R., \& Lapiedra, R. (2005). A literature-based innovation output analysis: Implications for innovation capacity. International Journal of Innovation Management, 9, 385-399.

Allen, P., \& Bennet, K. (2012). SPSS statistics a practical guide: Version 20. South Melbourne: Cengage Learning.

Allen, P., Bennett, K., \& Heritage, B. (2014). SPSS Statistics version 22: A practical guide. South Melbourne: Cengage Learning.

Andersén, J., \& Kask, J. (2012). Asymmetrically realized absorptive capacity and relationship durability. Management Decision, 50, 43-57. http://dx.doi.org/10.1108/00251741211194868

Anderson, N., de Drew, C. K. W., \& Nijstad, B. A. (2004). The routinization of innovation research: A constructively critical review of the state-of-the-science. Journal of Organizational Behavior, 25, 147-173.

Arbuckle, J. L. (2007). AMOS (Version 7) [Computer Software]. Chicago: SPSS

Argyis, C., \& Schon, D. (1978). Organizational learning: a theory of action perspective. Boston: Addison-Wesley.

Armbruster, H., Bikfalvi, A., Kinkel, S., \& Lay, G. (2008). Organizational innovation: The challenge of measuring non-technical innovation in large-scale surveys. Technovation, 28, 644-657. http://dx.doi.org/10.1016/j.technovation.2008.03.00

Bagozzi, R. (2011). Measurement and meaning in information systems and organizational research: Methodological and philosophical foundations. MIS Quarterly, 35, 261-292.

Barnett, H. G. (1953). Innovation: The basis of cultural change. New York: McGraw Hill.

Baron, R. M., \& Kenny, D. A. (1986). The moderator-mediator variable distinction in social psychological research: Conceptual, strategic and statistical considerations. Journal of Personality and Social Psychology, $51,1173-1182$. 
Battisti, G., \& Stoneman, P. (2010). How innovative are UK firms? Evidence from the fourth UK community innovation survey on synergies between technological and organizational innovations. British Journal of Management, 21, 187-206. http://dx.doi.org/10.1111/j.1467 8551.2009.00629.x

Benner, M. J., \& Tushman, M. L. (2003). Exploitation, exploration and process management: The productivity dilemma revisited. Academy of Management Review, 28, 238-256.

Brown, S. L., \& Eisenhardt, K. (1995). Product development: Past research, present findings and future directions. Academy of Management Review, 2, 343-378.

Buckley, M. R., Cote, J. A., \& Comstock, S. M. (1994). Measurement errors in the behavioral sciences: The case of personality / attitude research. Information Systems Research, 5, 48-73.

Campbell, D. T., \& Fiske, D. W. (1959). Convergent and discriminant validation by the multitratit-multimethod matrix. Psychological Bulletin, 56, 81-105. http://dx.doi.org/10.1037/h0046016

Cantner, U, \& Pyka, A. (1998). Absorbing technological spillovers: Simulations in an evolutionary framework. Industrial and Corporate Change, 7, 369-397.

Capra, F. J. (1996). The web of life: A new scientific understanding of living systems (1st ed.). New York: Harper Collins.

Cavana., R., Delahaye, B., \& Sekaran, U. (2001). Applied business research: Qualitative and quantitative methods. Australia: John Wiley \& Sons.

Chen, M. (2002). Transcending paradox: The Chinese "middle way" perspective. Asian Pacific Journal of Management, 19, 179-199.

Chesbrough, H. W. (2003). Open innovation: The new imperative for creating and profiting from technology. Boston: Harvard Business School Publishing.

Cheung, G. W., \& Lau, R. S. (2008). Testing mediation and suppression effects of latent variables: Bootstrapping with structural equation models. Organizational Research Methods, 11, 296-325. http://dx.doi.org/10.1177/1094428107300343

Chidi, M. I., Wang Z. M., Kwek, C. L., \& Yii, D. S. K. (2015). Exploring the impact of strategic proactivity on perceived corporate social responsibility in Nigeria's petroleum industry: A structural equation modeling approach. Asian Social Science, 11, 275-297. http://dx.doi.org/10.5539/ass.v11n4p275

Chinda, T., \& Mohamed, S. (2008). Structural equation model of construction safety culture. Engineering, Construction and Architectural Management, 15, 114-131. http://dx.doi.org/10.1108/09699980810852655

Christensen, C., \& Raynor, M. (2003). Innovator's solution: Creating and sustaining successful growth. Boston: Harvard Business School Press.

Cohen, W., \& Levinthal, D. (1990). Absorptive capacity: A new perspective on learning and innovation. Administrative Science Quarterly, 3, 128-152.

Cole, A. H. (1959). Business enterprise in its social setting. Cambridge, M.A.: Harvard University Press.

Cook, S., \& Brown, J. (1999). Bridging epistemologies: The generative dance between organizational knowledge and organizational knowing. Organization Science, 10, 381-400.

Cooper, R. G. (1979). The dimension of industrial new product success and failure. Journal of Marketing, 43, 93-103.

Cooper, R. G. (1994). Third-generation new product processes. Journal of Product Innovation Management, 11, 3-14.

Cooper, R. G., \& de Brentani, U. (1991). New industrial financial service: What distinguishes the winners. Journal of Product Innovation Management, 8, 75-90.

Daft, R. L. (1978). Essentials of organizations theory and design. Cincinnati, Ohio: South-Western College Publishing.

Damanpour, F. (1989). Structural correlates of organizational innovation. Unpublished manuscript, Rutgers University, Newark, NJ.

Damanpour, F. (1991). Organizational innovation: A meta-analysis of effects of determinants and moderators. Academy of Management Journal, 34, 555-590.

Damanpour, F., \& Evan, W. M. (1984). Organizational innovation and performance: The problem of 
organizational lag. Administrative Science Quarterly, 29, 392-409.

Damanpour, F., \& Gopalakrishnan, S. (2001). The dynamics of the adoption of product and process innovations in organizations. Journal of Management Studies, 38, 45-65.

Damanpour, F., Szabat, K. A., \& Evan, W. M. (1989). The relationship between types of innovation and organizational performance. Journal of Management Studies, 26, 587-601.

Davis, K. (1960). Can business afford to ignore social responsibilities? California Management Review, 2, 70-76.

Davis, S. (2009). The opportunity for peace in the Niger Delta. GEEI Green Paper Series, 2.

De Veaux, D. R., Velleman, P. F., \& Bock, D. E. (2005). Stats data and models (International Edition). Pearson Addison Wesley.

DeMaio, T. (1983). Approaches to developing questionnaires. Statistical Policy Working Paper 10, Washington, DC: Office of Management and Budget.

DeMaio, T., \& Wellens, T. (1997). Cognitive evaluation of proposed disability questions for the 1998 dress rehearsal. Unpublished Census Bureau report.

DeMaio, T., Mathiowetz, N., Rothgeb, J., Beach, M. E., \& Durant, S. (1993). Protocol for pretesting demographic surveys at the Census Bureau. Census Bureau Monograph, Washington, DC: U.S. Bureau of the Census.

Disselkamp, M. (2005). Innovations management: Instrumente und Methoden zur Umsetzung im Unternehmen. Wiesbaden: Gabler.

Dodgson, M. (1993). Organizational learning: A review of some literatures. Organization Studies, 14, 375-394.

Dosi, G. (1982). Technological paradigms and technological trajectories. A suggest interpretation of the determinants and directions of technical change. Research Policy, 2, 147-162.

Dosi, G. (1988). Sources procedures and microeconomic effects of innovation. Journal of Economic Literature, 26, 1120-1171.

Dougherty, D. (1995). Managing your core incompetencies for corporate venturing. Entrepreneurship Theory and Practice, 19, 113-135.

Dougherty, D., \& Hardy, C. (1996). Sustained production innovation in large, mature organisations: Overcoming innovation-to-organisation problems. Acad. Manage, 39, 1120-1153.

Durand, T. (1992). Dual technology trees: Assessing the intensity and strategic significance of technology change. Research Policy, 21, 361-380.

Easterby-Smith, M. (1997). Disciplines of organizational learning: Contributions and critiques. Human Relations, 50, 1085-1113.

Eisenhardt, K. M. (1989). Building theories from case study research. Academy of Management Review, 14, $532-550$.

Ericsson, K. A., \& Simon, H. A. (1980). Verbal reports as data. Psychological Review, 87.

Ericsson, K. A., \& Simon, H. A. (1984). Protocol Analysis. Massachusetts: The MIT Press.

Ettlie, J. E., Bridges, W. P., \& Okeefe, R. D. (1984). Organization strategy and structural differences for radical versus incremental innovation. Management Science, 30, 682-695.

Field, A. (2013). Discovering statistics using IBM SPSS statistics: And sex and drugs and rock $n$ 'roll. London, SAGE Publications.

Flatten, T. C., Greve, G. I., \& Brettel, M. (2011). Absorptive capacity and firm performance in SMEs: The mediating influence of strategic alliances. European Management Review, 8, 137-152. http://dx.doi.org/10.1111/j.1740-4762.2011.01015.x

Floyd, S. W., Lane, P. J. (2000). Strategizing throughout the organization: Managing role conflict in strategic renewal. Academy of Management Review, 25, 154-177. http://dx.doi.org/10.5465/AMR.2000.2791608

Garrido, M. J., \& Camarero, C. (2010). Assessing the impact of organizational learning and innovation on performance in cultural organizations. International Journal of Nonprofit and Voluntary Sector Marketing, 15(3), 215-232. http://dx.doi.org/10.1002/nvsm.384

Giorgina, Nelson, \& Lindsey. (2006). Experiments in producing nonresponse error, unpublished ms 
Grant, R. M. (1997). The knowledge-based view of the firm: Implications for management practice. Long Range Plan, 30, 450-454.

Gravetter, F. J., \& Wallnau, L. B. (2013). Statistics for the behavioral sciences. Belmont, CA: Wadsworth.

Green, S., Gavin, M., \& Aiman-Smith, L. (1995). Assessing a multidimensional measure of radical technological innovation. IEEE Transaction Engineering. Management, 3, 203-214.

Groves, R. M., Couper, M. P., Presser, Stanley, Singer, Eleanor, Tourangeau, Roger, Piani Acosta, Groves, R. M., \& Couper, M. P. (1998). Nonresponse in household interview surveys. New York: John Wiley \& Sons, Inc

Grulke, W., \& Sibler, G. (2003). Lessons in radical innovation. New York: Prentice Hall.

Guan, J. C., \& Liu, J. Y. (2007). Integrated innovation between technology and organization. International Journal of Innovation and Technology Management, 4, 415-432. http://dx.doi.org/10.1142/S02198770070 01168

Gupta, A. K., \& Wilemon, D. L. (1990). Accelerating the development of technology-based new products. California Management Review, 32, 24-44.

Hair, J. F., Anderson, R. E., Tatham, R. L., \& Black, W. C. (1998). Multivariate data analysis. Upper Saddle River: Prentice-Hall

Hair, J. F., Anderson, R. E., Tatham, R. L., \& Black, W. C. (2008). Multivariate data analysis. New Jersey: Prentice Hall

Hair, J. F., Black, W. C., Babin, B. J., \& Anderson, R. E. (2010). Multivariate data analysis. New Jersey: Pearson Education International.

Hair, J. F., Bush, R. P., \& Ortinau, D. J. (2003). Marketing research: Within a changing information environment. New York: McGraw-Hill.

Hair, J. F., Jr., Anderson, R. E., Tatham, R. L., \& Black, W. C. (2006). Multivariate data analysis. New Jersey: Prentice-Hall.

Hamel, G. (2006). The why, what and how of management innovation. Harvard Business Review, 72-84.

Helfat, C. E., \& Raubitschek, R. S. (2000). Product sequencing: Co-evolution of knowledge, capabilities and products. Strategic Management Journal, Special Issue 21, 961-979. http://dx.doi.org/10.1002/1097-0266 $(200010 / 11) 21: 10 / 11<961$

Herbst, T., \& Conradie, P. (2011). Leadership effectiveness in higher education: Managerial self-perceptions versus perceptions of others. Journal of Industrial Psychology, 37, 1-14. http://dx.doi.org/10.4102/sajip. v37i1.867.

Hornsby, J. S., Kuratko, D. F., \& Zahra, S. A. (2002). Middle managers' perception of the internal environment for corporate entrepreneurship: Assessing a measurement scale. Journal of Business Venturing, 17, 253. http://dx.doi.org/0.1016/S0883-9026 (00) 00059-8

Howell, D. C. (2013). Statistical Methods for Psychology. Belmont, CA: Wadsworth.

Huber, G. P. (1991). Organizational learning: The contributing processes and the literature. Organization Science, 2, 88-115.

Johnson, B., \& Christensen, L. (2008). Educational research: Quantitative, qualitative, and mixed approaches. California: SAGE Publications.

Kaiser, H. F. (1970). A second generation little jiffy. Psychometrika, 35, 401-415.

Kedia, B. L., \& Bhagat, R. S. (1988). Cultural constraints on transfer of technology across nations: Implications for research in international and comparative management. Academy of Management Review, 13(4), 559-571.

Kline, S. J., \& Rosenberg, N. (1986). An overview of innovation. In R. Landau, \& N. Rosenberg (Eds.), The Positive Sum Strategy. Harnessing Technology for Economic Growth (pp. 275-306). Washington, DC: National Academy Press.

Krubasik, E. G. (1988). Customize your product development. Harvard Business Review, 66, 46-52.

Kumar, M., Talib, S. A., \& Ramayah. (2013). Business research methods. New York: Oxford

Lager, T. (2002). A structural analysis of process development in process industry - A new classification system 
for strategic project selection and portfolio balancing. R\&D Management, 32, 87-95.

Lange, O. (1943). A note of innovations. The Review of Economics and Statistics, 25(1), 19-25.

Lawson, B., \& Samson, D. (2001). Developing innovation capability in organizations: A dynamic capabilities approach. International Journal of Innovation Management, 5, 377-400.

Lloyd, A. R., \& William, B. B. (2014). Organizational innovation: Current research and evolving concepts. Public Administration Review, 34, 284-293. http://dx.doi.org/10.1177/017084069201300304

Maclaurin, W. R. (1949). Invention and innovation in the radio industry. New York: Macmillan.

Malhotra, N. K. (2010). Marketing research: An applied orientation. New Jersey: Pearson Education.

Malhotra, N. K., Kim, S. S., \& Patil, A. (2006). Common method variance in IS research: A comparison of alternative approaches and a reanalysis of past research. Management Science, 52, 1865-1883. http://dx.doi.org/10.1287/mnsc.1060.0597

Marsh, H. W. (1988). Self description questionnaire: A theoretical and empirical basis for the measurement of multiple dimensions of preadolescent self-concept: A test of manual and a research monograph. TX: Psychological Corporation.

Marsh, H. W. (1990). The structure of academic self-concept: The Marsh/Shavelson Model. Journal of Educational Psychology, 82(4), 623-636.

Marsh, H. W., \& Balla, J. R. (1986). Goodness-of-Fit indices in confirmatory factor analysis: The effects of sample size. Retrieved from http://files.eric.ed.gov/fulltext/ED267091.pdf

Martinkenaite, I. (2012). Antecedents of knowledge transfer in acquisitions. Baltic Journal of Management, 7 , 167-184. http://dx.doi.org/10.1108/17465261211219796

Mathews, S. W. (2011). Internet usage, internet intensity and international sales performance SME's: a structural model approach. In Economic and Political Transformation: Implications and Impact on Global Business, Academy of International Business (AIB), Taipei, Taiwan.

Matusik, S. F., \& Heeley, M. B. (2005). Absorptive capacity in the software industry: Identifying dimensions that affect knowledge and knowledge creation activities. Journal of Management, 31, 549-572. http://dx.doi.org/10.1177/0149206304272293

Mol, M. J., \& Birkinshaw, J. (2009). The sources of management innovation: When firms introduce new management practices. Journal of Business Research, 62, 1269-1280. http://dx.doi.org/10.1016/j.jbusres. 2009.01.001

Mossholder, K. W., Bennett, N., Kemery, E. R., \& Wesolowski, M. A. (1998). Relationships between bases of power and work reactions: The mediational role of procedural justice. Journal of Management, 24, 533-552.

Mowery, D. C., Oxley, J. E., \& Silverman, B. S. (1996). Strategic alliances and interfirm knowledge transfer. Strategic Management Journal, 17, 77-91.

Nahapiet, I., \& Ghoshal, S. (1998), Social capital, intellectual capital and the organizational advantage. Academy of Management Review, 23, 242-266.

Nelson, R. R., \& Winter, S. G. (1982). An evolutionary model of economic change. Cambridge, Mass.: Harvard University Press.

Nonaka, I. R., Toyama, 1., \& Konno, N. (2000). A firm as a knowledge creating entity: A new perspective on the theory of the firm. Industrial and Corporate Change, 9, 1-20. http://dx.doi.org/10.1093/icc/9.1.1

OECD. (1991). The nature of innovation and the evolution of the productive system, OECD, Paris.

OECD. (2005). Oslo manuals. Guidelines for collecting and interpreting innovation data, OECD, Paris.

Oksenberg, L., Cannell, C., \& Kalton, G. (1991). New strategies for pretesting survey questions. Journal of Official Statistics, 7, 349-365.

Park, H. M. (2008). Univariate analysis and normality test using SAS, Stata, and SPSS. Working Paper. The University Information Technology Services (UITS) Center for Statistical and Mathematical Computing, Indiana University.

Pina e Cunha, M., Clegg, S., Rego, A. \& Neves, P. (2014). Organizational improvisation: From the constraint of strict tempo to the power of the Avant-Garde. Creativity and Innovation Management. http://dx.doi.org/10. 


\section{1/claim.12076}

Pleschak, F., \& Sabisch, H. (1996). Innovations management. Stuttgart: Schaeffer-Poeschel.

Podsakoff, P. M., \& Organ, D. W. (1986). Self-reports in organizational research: Problems and prospects. Journal of Management, 12, 531-544.

Podsakoff, P. M., MacKenzie, S. B., Lee, J.-Y., \& Podsakoff, N. P. (2003). Common method biases in behavioral research: A critical review of the literature and recommended remedies. Journal of Applied Psychology, 88, 879-903. http://dx.doi.org/10.1037/0021-9010.88.5.879

Preacher, K. J., \& Hayes, A. F. (2008). Asymptotic and resampling strategies for assessing and comparing indirect effects in multiple mediator models. Behavior Research Methods, 40, 879-891. http://dx.doi.org/10.3758/BRM.40.3.879

Redfield, R., Linton, R., \& Herskovits, M. J. (1936). Memorandum for the study of acculturation. American Anthropologist: New Series, 38(1), 149-152.

Reichwald, R., \& Piller, F. T. (2006). Interaktive Wertschoepfung: Open Innovation, Individualisierung und neue Formen der Arbeitsteilung. Wiesbaden: Gabler.

Saunders, M., Lewis, P., \& Thornhill, A. (2012). Research methods for business students (6th ed.). London: Prentice Hall.

Schumacker, R. E., \& Lomax, R. G. (2010). A beginner's guide to structural equation modeling (3rd ed.). New York: Routledge.

Schumpeter, J. A. (1942). Capitalism, socialism, and democracy. New York: Harper.

Sekaran, U. (2000). Research methods for business: A skill-building approach. NY: John Wiley.

Sekaran, U. (2013). Research methods for business: A skill-building approach. NY: John Wiley.

Senge P. (1990). The fifth discipline. U.S.A.: Currency.

Senge, P. (1999). Learning for a change. Fast Co 24,178-185.

Senge, P. (1999). Towards an ecology of leadership: Development journeys of three leaders, change and development journeys into a pluralistic world. Annual Meeting of the Academy of Management, Chicago

Teece, D. (1986) Profiting from technological innovation: Implications for integration, collaboration, licensing and public policy. Research Policy, 15(6), 285-305

Teece, D. J., Pisano, G., \& Shuen, A. (1997). Dynamics capabilities and strategic management. Strategic Management Journal, 18, 509-33.

Teo, T. (2011). Considering common method variance in educational technology research. British Journal of Educational Technology, 42, 94-96.

Tidd, J., \& Bessant, J. (2005). Managing innovation: Integrating technological, market, and organizational change (3rd ed.). West Essex: Wiley.

Tomala, F., \& Sénéchal, O, (2004). Innovation management: A synthesis of academic and industrial points of view. International Journal of Project Management, 22, 281-287. http://dx.doi.org/10.1016/j.ijproman. 2003.06

Turner, C., \& Martin, E. (1984). Surveying subjective phenomena, 1 and 2, New York: Russell Sage.

Tushman, M., \& Anderson, P. (1986). Technological discontinuities and organizational environments. Administrative Science Quarterly, 31, 439-465.

Utterback, J. M. (1975). Innovation in industry and the diffusion of technology. Science, 183, 620-626.

Utterback, J. M. (1994). Mastering the dynamics of innovation: How companies can seize opportunities in the face of technological change. Boston M.A.: Harvard Business School Press

Wang, S., \& Cheung, W. (2004). E-business adoption by travel agencies: Prime candidates for mobile e-business. International Journal of Electronic Commerce, 8, 43.

West, J., \& Gallagher, S. (2006). Challenges of open innovation: The paradox of firm investment in open-source software. $R \& D$ Management, 36, 319-331. http://dx.doi.org/10.1111/j.1467-9310.2006.00436.x

West, M. A., \& Farr, J. L. (1990). Innovation at work. Innovation and Creativity at Work: Psychological and Organizational Strategies (pp. 3-13). West, M.A. and Farr, J.L. eds. Chichester, England: John Wiley \& 
Sons.

Weston, R. (2006). A brief guide to structural equation modeling. The Counseling Psychologist, 34, 719-751. http://dx.doi.org/10.1177/0011000006286345

William, G., \& Zikmund, S. W. (2014). Marketing research. Nelson Australia Pty Limited.

Willis, G. (1994). Cognitive interviewing and questionnaire design: A training manual, cognitive methods. Staff Working Paper Series, No. 7, Hyattsville, MD: U.S. National Center for Health Statistics, Office of Research and Methodology.

Wischnevsky, J. D., Damanpour, F., \& Me'ndez, F. A. (2011). Influence of environmental factors and prior changes on the organizational adoption of changes in products and in technological and administrative processes. British Journal of Management, 22, 132-149. http://dx.doi.org/10.1111/j.1467-8551.2010. 00700.x

Wolfe, L. M. (1992). Sewell Wright on the method of path coefficients: An annotated bibliography. Structural Equation Modeling, 6, 280-291.

Wright, S. (1920). The relative importance of heredity and environment in determining the piebald pattern of guinea-pigs. Proceedings of the National Academy of Sciences, 6, 320-332.

Wright, S. (1921). Correlation and causation. Journal of Agricultural research, 20, 557-585.

Xia, C. Y., Wang, L., Sun, S. W. \&, Wang, J. (2012). An SIR model with infection delay and propogation vector in complex networks. Nonlinear Dyn, 69, 927-934. http://dx.doi.org/10.1007/s11071-011-0313-y

Yang, J. (2012). Innovation capability and corporate growth: An empirical investigation in China. Journal of Engineering and Technology Management, 29, 34-46. http://dx.doi.org/10.1016/j.jengtecman.2011.09.004

Zahra, S. A., \& George, G. (2002). Absorptive capacity: A review, reconceptualization, and extension. Academy of Management Review, 27, 185-203.

\section{Copyrights}

Copyright for this article is retained by the author(s), with first publication rights granted to the journal.

This is an open-access article distributed under the terms and conditions of the Creative Commons Attribution license (http://creativecommons.org/licenses/by/3.0/). 